GEFAD / GUJGEF41(2): 1227-1246(2021)

\title{
Fen Lisesi Öğrencilerinin Demografik Özellikleri ve Tercih Ettikleri Müzik Türlerine Göre Okula Yönelik Tutumlarının İncelenmesi"
}

\section{Investigation of Science High School Students' Attitudes Towards School According to Demographic Features and Preferred Music Types}

\author{
Oğuz KOÇ${ }^{1}$, İdil EKINAY ${ }^{2}$

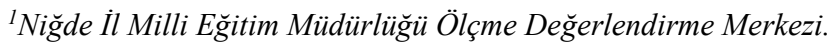 \\ oguzkoc20@hotmail.com \\ ${ }^{2}$ Niğde Fen Lisesi.idilekinay@gmail.com
}

Makalenin Geliş Tarihi: 26.04.2020

Yayına Kabul Tarihi: 27.06.2021

$\ddot{O} Z$

Bu çalışmanın amacı, fen lisesi ögrencilerinin demografik özellikleri ve tercih ettikleri müzik türlerine göre okula yönelik tutumlarının farklılaşıp farklılaşmadı̆̆ını ortaya koymaktır. Çalışma, ilişkisel tarama modelinde olup Niğde ilindeki bir fen lisesinden 334 ögrenci ile gerçekleştirilmiştir. Veri toplama aracı olarak; demografik bilgi formu ve okula yönelik tutum ölçeği kullanılmıştır. Veri analizinde toplanan verilerin parametrik test koşullarını sağlamadı̆̆ incelenerek işlemler yapılmıştır. Cinsiyet açısından ögrencilerin okula yönelik tutumlarında farklılaşmadığı bulunmuştur. Sınıf düzeyi açısından okula yönelik tutum puanları incelendiğinde dokuzuncu sınıf öğrencilerin, on birinci ve on ikinci sinıf öğrencilere göre yüksek puan ortalamasına sahip olduğu görülmüştür. Öğrencilerin baskın olarak tercih ettikleri müzik türlerine göre okula yönelik tutumlarında da anlaml farklılık bulgusu elde edilmiştir. Hangi gruplar arasında farklılık olduğunu bulmak amacılla gerçekleştirilen analiz sonucunda, Metal Müzik tercihinde bulunan öğrencilerin, Türk Halk Müzik-Arabesk/Fantezi Müzik-Pop Müzik-Rap Müzik-Tasavvuf Müzik tercihinde bulunan öğrencilere göre daha düşük okula yönelik tutum puanına sahip olduğu, Rock Müzik tercihinde bulunan ögrencilerin, Türk Halk Müzik-Pop Müzik türlerini tercih eden ögrencilere göre daha düşük okula yönelik tutum puanına sahip olduğu

\footnotetext{
* Alıntılama: Koç, O. ve Ekinay, İ. (2001). Fen Lisesi Öğrencilerinin Demografik Özellikleri ve Tercih Ettikleri Müzik Türlerine Göre Okula Yönelik Tutumlarının İncelenmesi. Gazi Üniversitesi Gazi Ĕ̈itim Fakültesi Dergisi, 41(2), 1227-1246.

** Bu çalışma TÜBİTAK 50. Liselerarası Araştırma Projeleri Yarışması Türkiye Finallerinde Psikoloji alanında sergilenmiştir
} 
sonucuna ulaşılmıştır. Alanyazın, elde edilen bulgular ve sınırlılıklar çerçevesinde sonuçlar değerlendirilmiştir.

Anahtar Sözcükler: Lise öğrencisi, Müzik türü, Okula yönelik tutum, Fen lisesi.

\section{ABSTRACT}

The aim of this study is to reveal whether science high school students' attitudes towards school differ according to their demographic characteristics and the types of music they prefer. The study was conducted in a relational screening model and was conducted with 334 students from a science high school in the province of Niğde. As a data collection tool; demographic information form and attitude scale towards school were used. In data analysis; The procedures were examined by examining that the collected data did not meet the parametric test conditions. In terms of gender, it was found that students did not differ in their attitudes towards school. When the attitude points towards the school in terms of grade level were examined, it was seen that ninth grade students had a higher average score compared to the eleventh and twelfth grade students. There was also a significant difference in students' attitudes towards school according to the music styles they prefer. As a result of the analysis conducted to find out which groups are different; It was found that students who prefer metal music have a lower school attitude score compared to students who prefer Turkish Folk Music-Arabesque / Fantasy Music-Pop Music-Rap Music-Sufi Music. It is concluded that students who prefer Rock Music have a lower school attitude score than students who prefer Turkish Folk Music-Pop Music genres. The results are evaluated within the framework of the findings and limitations.

Keywords: High school student, Music type, Attitude towards school, Science high school

\section{GíRiş}

Bilinen tüm tarihsel kaynaklarda görülmektedir ki müzik insanların sevinçleri, hüzünleri ve diğer tüm duygularını kapsayacak şekilde hayatlarında yer almaktadır. Düğün, cenaze, savaş, bayram gibi etkinliklerde insanları hangi duygu durumunda olmasına konusunda müziğin yönlendirebilme özelliği vardır (Uluçay, 2018). Aynı şekilde müzik toplumların kültürleri ve tarihleri hakkında da bilgi veren en temel kaynaklardandır. Tarih boyunca insanın tüm yaşam noktalarında etkisi olan müziğin bireyin iç dünyasını yönlendirmesinde de etkili olduğu yadsınamaz bir gerçekliktir (Yağışan, 2013). İslam Medeniyetinde Zekeriya ErRazi, Farabi ve İbni-i Sina psişik hastalıkların tedavisinde müziği etkin olarak kullanmışlardır (Çoban, 2005). Müziğin psikolojik etkisinin sadece insanlar üzerinde olmayıp diğer canlılar üzerinde de olduğu bilinmektedir (Sezer, 2011). $\mathrm{Bu}$ kapsamda hayvanlar, bitkiler ve benzeri diğer tüm canlılarda daha fazla verim elde 
etmek amacıyla müzik çalışmalarının gerçekleştirildiği zaman zaman medyada yer almaktadır. Günümüz dünyasında her alanda değişmeler yaşanmasına karşın insanlık üzerinde müziğin etkisinin hala devam ettiği ifade edilebilir. Film müzikleri, düğün müzikleri, asansörde çalan müzikler ve hayatımızda yer alan her alanda müzik vardır. Müzik ile insanların sosyalleşmeleri ve hayat sürecinde daha yoğun duygular yaşamaları sağlanır (Williams, 2008). Bu doğrultuda müziğin insanlar üzerinde doğru kullanılması, olumlu sonuçlar verebilecekken kontrolsüz ve yanlış kullanımı ise olumsuz sonuçlara neden olabilecektir (Sezer, 2011).

Müzik, karakter oluşumunun kritik bir yaşam dönemi olan ergenlerde sosyal varlığını konumlandırabilmesi için önemli bir kavramdır. Seçilen müzik tarzları ile birlikte yaşam tarzı tercihi de beraberinde gelebilmektedir. Pop, arabesk, rock ve diğer müzik tarzları kişilerin ya da grupların hayata dair bakış açılarını yapılandırdıkları temel kaynaklar olan inanç ve adalet sistemi haline gelmektedir (Güven, 2017). Bireyler sahip oldukları görüşlere yönelik destek arar ve görüşlerini sağlamlaştırmak ister, tercih edilen müzik türlerinin yaşama yönelik görüşleri ise bu ihtiyaca destek verebilmektedir (Artemiz, 2009). North, Desborough ve Skarstein (2005) dünya çapında geniş katılımlı gerçekleştirdikleri çalışmalarında, müzik tercihinin kişilik ile ilişkili olduğunu bulmuşlardır. Klasik, jazz, blues, folk ve benzeri müzik tercihinde olanların; yaratıcı, esnek ve liberal görüşlü oldukları sonucu elde edilmiştir. Heavy metal, rock ve benzeri müzik tercihinde olanların; aktif ve risk alma ihtimali yüksek olduklarını bulmuşlardır. Pop, country, dini ve benzeri müzik tercihinde bulunanların; neşeli ve daha açık sözlü olduğunu sonucuna ulaşılmıştır. Hip-hop, soul, funk ve benzeri müzik türünü tercih edenlerin ise daha konuşkan, enerjik ve açık görüşlü oldukları sonucu elde edilmiştir.

Ergenlik dönemi gençlerin kişilik karmaşası içerisinde geçirdikleri stresli bir dönem olarak ifade edilebilir. Ergenler bu dönemde aileleri ile daha az etkileşime geçerek daha çok akranları ile iletişimlerini arttırırlar. $\mathrm{Bu}$ değişim ile birlikte müziği; kişiliklerini ifade edebilmek, akran ilişkilerini arttırmak, duygusal bağlarını arttırmak, otoriteye baş kaldırmak ve bağımsızlıklarını ortaya koymak amacıyla hayatlarında daha önemli bir konuma yerleştirirler (Artemiz, 2009). Amerika'da gerçekleştirilen bir çalışmada 
gençlerin ortalama kırk saat müzik dinledikleri bulunmuştur (Uluçay, 2018). Ergenlerin büyük bir zaman ayırdığı ve karakterini şekillendirilmesinde etkili olduğu görünen müzik türlerinin etkileri konusunda daha dikkatli olunması gerektiği ifade edilebilir.

Ergenlerin kendi kişiliklerini oluşturdukları süreçte, zamanlarının önemli bir kısmını geçirdikleri okul süreci elzem bir hal almaktadır. Bu süreçte ergenlerin sosyalleşmesi, kendi yeteneklerini keşfetmesi, hedeflerini somutlaştırması ve kariyerine yön vermesi gibi birçok sorumluluğu bulunmaktadır. Yine bu süreçte ergenlerin oluşturdukları kişilik özellikleri de okula yönelik tutumlarını yönlendirebilmektedir. Yapılan araştırmalar göstermektedir ki okula yönelik tutumun olumlu olması hedeflenen eğitim sürecinin etkin yaşanmasına katkı sağlamaktadır. Adıgüzel ve Karadaş (2013) gerçekleştirdikleri çalışmada ortaöğretim kademesi 10. sınıf öğrencilerde devamsızlık sayısı fazla olanların az olanlara göre okula yönelik tutumlarının daha olumsuz olduğunu bulmuşlardır. Ainley (1994) gerçekleştirdiği çalışmasında okula yönelik tutumun akademik başarıyı da olumlu etkilediğini bulmuştur. Kısaca denilebilir ki okulu seven bir öğrencinin eğitime bakışı, eğitim süreci ve eğitim çıktıları ile okulu sevmeyen, okuldan kaçan bir öğrencinin durumu arasında çok büyük fark olacaktır (Alıcı, 2013).

Okula yönelik tutumu daha iyi açıklayabilmek amacıyla, farklı değişkenlere göre çalışmaların yürütüldüğü ifade edilebilir. Yapılan çalışmalarda sıkılıkla demografik özelliklerin ele alındığı görülmektedir. Cinsiyet bağımsız değişkeni açısından gerçekleştirilen çalışmalarda farklı bulgular olmasına karşın, kız öğrencilerin erkek öğrencilere göre okula yönelik tutumlarının daha olumlu olduğu çoğunlukla görülmektedir (Adıgüzel ve Karadaş, 2013; Alıcı, 2013; Gülcemal, 2019; Koç, 2019; Pişkin, 2005; Sözbilir, Akıllı ve Ozan, 2010). Bir diğer ele alınan demografik değişken ise sınıf seviyesidir. Alanyazında sınıf seviyesi değişkenine göre okula yönelik tutumun ortaöğretim kademesi açısından farklılaştığı bulgusu sıklıkla görülmektedir (Alıcı, 2013; Gülcemal, 2019; Sözbilir, Akıllı ve Ozan, 2010).

Kişisel-sosyal, mesleki ve eğitsel açılardan kritik bir dönem olan ortaöğretim kademesi, öğrencilerinin tercih ettikleri müzik türleri geleceklerine yön vermede etkileyici bir faktör olurken, okula yönelik tutumda öğrencinin gelişimi açısından çok önemli başka 
bir faktör olarak karşımıza çıkmaktadır. Okula yönelik tutumun daha iyi anlaşılabilmesi için yeni çalışmaların gerekli olduğu, aynı zamanda yapılan literatür taramasında öğrencilerin tercih ettikleri müzik türlerine göre okula yönelik tutumlarını inceleyen herhangi bir çalışma olmadığı söylenebilir.

Yapılan açıklamalardan hareketle bu çalışmada problem cümlesi şu şekilde oluşturulmuştur:

- Fen lisesi öğrencilerinin cinsiyet, sınıf düzeyi ve tercih ettikleri müzik türlerine göre okula yönelik tutumları farklılaşmakta mıdır?

Alt problemler ise şu şekilde oluşturulmuştur:

Fen lisesi öğrencilerinin;

1. Cinsiyetlerine göre okula yönelik tutumları farklılaşmakta mıdır?

2. Sınıf düzeylerine göre okula yönelik tutumları farklılaşmakta mıdır?

3. Tercih ettikleri müzik türüne göre okula yönelik tutumları farklılaşmakta midir?

\section{YÖNTEM}

\section{Araştırma Modeli}

Araştırma, ilişkisel tarama modelinde yapılmıştır. İlişkisel tarama modeli, iki ve daha çok sayıdaki değişken arasında, birlikte değişim varlığını ve derecesini belirlemeyi amaçlayan bir araştırma modeli olup bu tür bir düzenlemede, aralarında ilişki aranacak değişkenler ayrı ayrı sembolleştirilir. Bu sembolleştirme, ilişkisel bir çözümlemeye olanak verilecek şekilde yapılmak zorundadır (Karasar, 2017). 


\section{Çalışma Grubu}

Çalışma grubunu, 2018-2019 Eğitim Öğretim Yılı Niğde ilinde yer alan bir fen lisesindeki 334 öğrenci oluşturmaktadır. Katılımcıların cinsiyet ve sınıf düzeylerine yönelik bilgiler Tablo 1'de yer almaktadır.

Tablo 1. Katılımcılara ait demografik bilgiler

\begin{tabular}{llll}
\hline & & $\mathrm{f}$ & $\%$ \\
\hline Cinsiyet & K1z & 170 & 50.9 \\
& Erkek & 164 & 49.1 \\
& Toplam & 334 & 100 \\
\hline Sinif & 9. Sinif & 100 & 29.9 \\
& 10. Sinif & 82 & 24.6 \\
& 11. Sinif & 81 & 24.3 \\
& 12. Sinif & 71 & 21.3 \\
& Toplam & 334 & 100 \\
\hline
\end{tabular}

Tablo 1 incelendiğinde, araştırma katılımcılarının yaklaşık \%51'inin kız öğrencilerden oluşuyorken yaklaşık 49'u erkek öğrencilerden oluştuğu görülmektedir. Sinıf düzeyleri açısından katılımcıların dağılımlarına bakıldığında, 9. sınıf öğrenci oranının yaklaşık \%30 olduğu, 10. sınıf öğrenci oranının \%25, 11. sınıf öğrenci oranının \%24 ve 12. sınıf öğrenci oranının \%21 olduğu görülmektedir.

\section{Veri Toplama Araçları}

Bilgi Formu

Katılımcıların demografik bilgileri olan sınıf seviyesi, cinsiyet ile tercih ettikleri müzik türleri hakkında bilgilerin sorulduğu okula yönelik tutum ölçeği üstünde yer alan bölümdür. 
Okula Yönelik Tutum Ölçeği

Ortaöğretim kademesinde yer alan öğrencilerin okula yönelik tutumlarının belirlenmesi amacıyla 5'li likert tipinde ve yirmi maddelik olarak Alıcı (2013) tarafindan geliştirilmiştir. Ölçekte yer alan maddelerin 12 tanesi olumlu ifadelerle oluşturulmuşken sekiz maddesi ise olumsuz ifadelerle oluşturulmuştur. Ölçek üç bileşenli bir yapıya sahiptir. Ölçeğin bileşenleri: Kişisel Gelişimin Engeli Olarak Okul, Kişisel Gelişimin Destekleyicisi Olarak Okul ve Özlenen Bir Varlık Olarak Okul Şeklindedir. Ancak yapılan analizlerde tek boyutlu bir yapıya sahip olduğu bulgusuna da erişilmiştir. Ölçeğin bütününe yönelik Cronbach Alpha güvenirlik katsayısı incelendiğinde .90 olarak bulunmuştur. Alt boyutlarında ise $.87, .81$ ve .78 olarak bulunmuştur. $\mathrm{Bu}$ çalışmada toplam puan açısından Cronbach Alpha güvenirlik katsayısı 91 bulunmuştur. Alt boyutlar incelendiğinde ise sırasıyla Cronbach Alpha güvenirlik katsayıları .87, .86, .78 olarak bulunmuştur.

\section{Etik Kurallara Uygunluk}

Araştırmanın kavramsal çerçevesinin hazırlanmasında, verilerin toplanma, analiz ve yorumlanması aşamalarının tamamında etik kurallara uygun hareket edilmesine özen gösterilmiştir. Çalışma konusu ile ilgili eserlere atıflar yapılmıştır. Bu araştırma birinci yazarın danışmanlığında ikinci yazar tarafından 2018-2019 eğitim öğretim yılında gerçekleştirilen TÜBİTAK 50. Liselerarası Araştırma Projeleri Yarışması Türkiye Finallerinde Psikoloji alanında sergilenmiştir. Veriler, Niğde İl Milli Eğitim Müdürlüğü’nün 13.12.2018 tarihli ve 61900286-20-E.24065158 say1lı resmi yazıs1 doğrultusunda gönüllü katılımcılardan toplanılmıştır. İlgili resmi yazı Ek-1'de sunulmuştur.

\section{Verilerin Toplanması ve Analizi}

Öncelikle veri toplama aracı geliştiricisinden daha sonra ise ilgili araştırmanın gerçekleştirilebilmesi için Niğde İl Milli Eğitim Müdürlüğünden izin alınmıştır. Bir sonraki aşama olarak okuldaki öğrencilere çalışmanın amacı hakkında bilgilendirme 
faaliyetleri yürütülmüş ve ölçme aracı dağıtılmıştır. Öğrencilerden formlar $\quad$ geri toplanarak analiz işlemleri gerçekleştirilmiştir.

Toplanan veriler bilgisayar ortamına aktarılarak SPSS 24.0 paket programı ile araştırma analizleri gerçekleştirilmiştir. Bu süreçte verilerin araştırma soruları çerçevesinde analiz edilebilmesi için sayıltıları karşılayıp karşılamadığı test edilmiştir. Analizler öncesinde verilerin normal dağılım gösterip göstermediğini anlamak amacıyla basıklık ve çarpıklık değerleri incelenmiştir. Çarpıklık ve basıklık değerlerinin -1 ile +1 arasında olması verilerin normal dağılım gösterdiğine işaret etmektedir (Hair, Hult, Ringle ve Sarstedt, 2016). Verilerin homojenliği ön koşulu için ise Levene F testi yapılmıştır. Levene F testi sonucunun anlamlı çıkmaması $(\mathrm{p}>.05)$ varyansların homojen olduğu anlamına gelmektedir (Büyüköztürk, 2017). Koşullar doğrultusunda parametrik ya da nonparametrik testler yapılmıştır. Araştırmada anlamlılık düzeyi .05 olarak kabul edilmiş̧ir. $\mathrm{Bu}$ kapsamda mevcut çalışmada, cinsiyete göre okula yönelik tutum için bağımsız örneklem $t$ testi, sınıf düzeyine göre okula yönelik tutum için tek yönlü anova ve tercih edilen müzik türüne göre okula yönelik tutum için Kruskal-Wallis $\mathrm{H}$ Testi kullanılmıştır.

\section{BULGULAR}

\section{Öğrencilerin Cinsiyetlerine Göre Okula Yönelik Tutumları}

Öğrencilerin cinsiyetlerine göre verilerinin normal dağılım sergileyip sergilemediklerini anlamak için çarpıklık ve basıklık değerleri incelenmiştir. Çarpıklık değerlerinin -.416 ile -.413 olduğu, basıklık değerlerinin ise -.089 ile .323 arasında olduğu görülmüştür. Gerçekleştirilen Levene testi sonucu varyansların homojen olduğu bulunmuştur $(\mathrm{p}=.07>\mathrm{a}=.05) \quad$ Koşullar incelenmesinden sonra bağımsız örneklem $\mathrm{t}$ testi gerçekleştirilmiştir. Bağımsız örneklem $t$ testi, iki ilişkisiz örneklem ortalamaları arasındaki farkın anlamlı olup olmadığını ortaya koymak için kullanılan parametrik bir testtir (Büyüköztürk, 2017). Elde edilen bulgular Tablo 2'de gösterilmiştir. 
Tablo 2. Okula yönelik tutum düzeylerinin cinsiyete göre dağılım sonuçları

\begin{tabular}{lcccccccccc}
\hline \multicolumn{10}{c}{ Cinsiyet } \\
\hline \multicolumn{10}{c}{ Kadın } & \multicolumn{1}{c}{ Erkek } \\
\hline OYT & $\mathrm{n}$ & Arit. Ort & ss & $\mathrm{n}$ & Arit. Ort & ss & sd & $t$ & $p$ \\
\hline Toplam & 170 & 63.22 & 14.07 & 164 & 64.55 & 12.74 & 332 & -.901 & .368 \\
\hline
\end{tabular}

Tablo 2'deki sonuçlar incelendiğinde, okula yönelik tutum düzeylerinin cinsiyete göre farklılaşmadığı belirlenmiştir ( $\mathrm{t}=-.90, \mathrm{p}>.05)$.

\section{Öğrencilerin Sınıf Seviyelerine Göre Okula Yönelik Tutumları}

Öğrencilerin sınıf seviyelerine göre verilerinin normal dağılım sergileyip sergilemediklerini anlamak için çarpıklık ve basıklık değerleri incelenmiştir. Çarpıklık değerlerinin -.487 ile -.224 arasında değiştiği, basıklık değerlerinin ise -.356 ile .568 arasında değiştiği ve normal dağıldığı görülmüsştür. Gerçekleştirilen Levene testi sonucu varyansların homojen olduğu bulunmuştur $(\mathrm{p}=.50>\mathrm{a}=.05)$ Koşullar incelenmesinden sonra tek yönlü anova testi gerçekleştirilmiştir. Tek yönlü anova analizi, ilişkisiz iki ya da daha fazla örneklem ortalaması arasındaki farkın anlamlı olup olmadı̆̆ını test etmek amacıyla kullanılan parametrik bir testtir. Elde edilen bulgular Tablo 3 'te gösterilmiştir.

Tablo 3. Okula yönelik tutum düzeylerinin sinıf düzeyine göre dağılım sonuçları

\begin{tabular}{rccccccc}
\hline Sinıf Düzeyi & $\mathrm{n}$ & Arit. Ort. & ss & sd & $F$ & $p^{*}$ & Anlamlı Fark \\
\hline 9. Sinıf & 100 & 68.57 & 12.15 & & & & \\
10. Sinıf & 82 & 64.72 & 12.71 & 3 & 8.593 & .000 & 9. Sinıf-11. Sinıf \\
11. Sinıf & 81 & 59.32 & 13.83 & 3 & & & 9. Sinıf-12. Sinıf \\
12. Sinıf & 71 & 61.48 & 13.46 & & & & \\
\hline$p^{*}=<.05$ & & & & & & &
\end{tabular}

Tablo 3 incelendiğinde, öğrencilerin okula yönelik tutum ortalama puanlarının sınıf düzeylerine göre anlamlı bir farkl1lık oluşturduğu görülmektedir $(F=8.593 ; p<0.05)$. Farkların hangi gruplar arasında olduğunu belirlemek üzere Post Hoc testlerden "Bonferroni” testi yapılmıştır. Öğrencilerin sınıf seviyelerine göre okula yönelik tutum düzeyleri ortalamaları incelendiğinde, dokuzuncu sınıf öğrencilerin okula yönelik tutum düzeylerinin $\left(\overline{\mathrm{X}}_{9}=68.57\right)$ on birinci sınıf öğrencilerin $\left(\overline{\mathrm{X}}_{11}=59.32\right)$ ve on ikinci sinıf öğrencilerin $\left(\overline{\mathrm{X}}_{12}=61.48\right)$ okula yönelik tutum düzeylerinden daha yüksek olduğu bulgusuna ulaşılmıştır. 
Sınıf düzeyi bağımsız değişkeninin etki büyüklüğünü belirlemek için eta kare ( 2 2) değeri incelenmiştir. Etki büyüklükleri; .01, .06 ve .14 düzeyindeki eta kare değerlerini, aynı sırayla küçük, orta ve geniş etki büyüklüğü olarak yorumlanır (Büyüköztürk, 2017). Bu durumda sınıf düzeyi değişkeni açısından elde edilen eta kare değerinin ( $\eta 2=.078$ ) okula yönelik tutum düzeyi üzerinde orta düzeyde bir etki büyüklüğ̈̈ne sahip olduğu ifade edilebilir.

\section{Öğrencilerin Tercih Ettikleri Müzik Türlerine Göre Okula Yönelik Tutumları}

Öğrencilerin tercih ettikleri müzik türlerine bağlı olarak okula yönelik tutumlarında farklı olup olmadığını analiz etme yöntemi belirlenirken gruplarda yer alan öğrenci sayılarına bakılmıştır. Dağı̆lımın normalden aşırı sapma göstermediği varsayımının karşılandığını ileri sürebilmesi için örneklem büyüklüğümün genellikle otuz ve üzeri olması gerekmektedir (Büyüköztürk, 2017). Farklı müzik türü tercihlerinde otuz altında öğrenci grupları olması sebebiyle analizler non parametrik bir test olan Kruskal Wallis H Testi gerçekleştirilmiştir. Kruskal Wallis H Testi ilişkisiz iki ya da daha fazla örneklem ortalamasının birbirlerinden anlamlı düzeyde farklılaşıp farklılaşmadığını ortaya koyan non-parametrik bir testtir (Büyüköztürk, 2017). Elde edilen bulgular Tablo 4 'te gösterilmiştir. 
Tablo 4. Okula yönelik tutumun tercih edilen müzik türüne göre Kruskal Wallis H Testi sonuçları

\begin{tabular}{rcccccc}
\hline Tercih Edilen Müzik Türü & n & Sira Ort. & sd & $X^{2}$ & $p^{*}$ & Anlamlı Fark \\
\hline Türk Halk Müziği & 20 & 227.53 & & & & Türk Halk- \\
Türk Sanat Müziği & 20 & 166.48 & & & & Rock \\
Arabesk/Fantezi Müzik & 26 & 184.21 & & & & Türk Halk- \\
Pop Müzik & 64 & 198.97 & & & & Metal \\
Jazz Müzik & 19 & 166.13 & & & & Arabesk \\
Rock Müzik & 60 & 139.38 & \multirow{2}{*}{10} & 47.43 & .000 & Fantezi-Metal \\
Metal Müzik & 23 & 76.70 & & & & Pop-Rock \\
Klasik Batı Müziği & 22 & 168.61 & & & & Pop-Metal \\
Rap Müzik & 38 & 165.50 & & & & Metal-Rap \\
Tasavvuf Müzik & 20 & 212.73 & & & & Metal- \\
Diğer & 22 & 136.59 & & & & Tasavvuf \\
\hline
\end{tabular}

$p^{*}<.05$

Tablo 4 incelendiğinde, öğrencilerin tercih ettikleri müzik türlerine göre okula yönelik tutum puan ortalamalarında anlamlı bir farklılık olduğu görülmektedir $\left(\mathrm{X}^{2}=47.43\right.$; $\mathrm{p}<0.05)$. Grupların sıra ortalamaları dikkate alındığında, okula yönelik tutum konusunda Türk Halk Müzik türünü tercih eden öğrencilerin en yüksek puana Metal Müzik türünü tercih eden öğrencilerin ise en az puana sahip olduğu görülmektedir.

Hangi gruplar arasında anlamlı farklılığın olduğunu bulmak için birkaç farklı yol bulunmaktadır. Büyüköztürk’e (2017) göre birinci ihtimal ikili kombinasyonlar için Mann Whitney U-testi uygulanmasıdır. İkinci ihtimal ise Dunn's testidir. Bir diğer seçenek ise, SPSS 18 ve üstü versiyonlarında yer alan Kruskal Wallis H testi sonrası parametrik olmayan çoklu karşılaştırma testidir. Bu çalışmada bahsedilen son seçenek kullanarak gruplar arası anlamlı farklılıklar değerlendirilmiştir.

Analiz sonucunda, Türk Halk Müzik türünü tercih eden öğrenciler ile Rock Müzik türünü tercih eden öğrenciler arasında, Türk Halk Müzik türünü tercih eden öğrenciler ile Metal Müzik türünü tercih eden öğrenciler arasında, Arabesk/Fantezi Müzik türünü tercih eden öğrenciler ile Metal Müzik türünü tercih eden öğrenciler arasında, Pop Müzik türünü tercih eden öğrenciler ile Rock Müzik türünü tercih eden öğrenciler arasında, Pop Müzik türünü tercih eden öğrenciler ile Metal Müzik türünü tercih eden 
öğrenciler arasında, Metal Müzik türünü tercih eden öğrenciler ile Rap Müzik türünü tercih eden öğrenciler arasında ve Metal Müzik türünü tercih eden öğrenciler ile Tasavvuf Müzik türünü tercih eden öğrenciler arasında anlamlı farklılık olduğu bulunmuştur.

Ortalama farkları dikkate alındığında, Metal Müzik tercihinde bulunan öğrencilerin, Türk Halk Müzik-Arabesk/Fantezi Müzik-Pop Müzik-Rap Müzik-Tasavvuf Müzik tercihinde bulunan öğrencilere göre daha düşük okula yönelik tutum puanına sahip olduğu, Rock Müzik tercihinde bulunan öğrencilerin, Türk Halk Müzik-Pop Müzik türlerini tercih eden öğrencilere göre daha düşük okula yönelik tutum puanına sahip olduğu ifade edilebilir.

\section{TARTIŞMA ve SONUÇ}

Gerçekleştirilen çalışmada Niğde ilinde bulun bir fen lisesindeki öğrencilerin cinsiyet, sınıf düzeyi ve tercih ettikleri müzik türlerine göre okula yönelik tutumları incelenmiştir. Cinsiyet değişkeni açısından mevcut çalışmada herhangi bir farklılık bulgusuna ulaşılmamıştır. Alanyazın incelendiğinde, mevcut çalışma bulgularına paralel olarak lise öğrencilerinde cinsiyet açısından okula yönelik tutumda farklılık olmadığı bulgusu elde edilen çalışmalar görülmektedir (Başaran ve Yıldırım, 2017; Shah, Visal ve Shah, Anand, 2018). Bununla birlikte farklılık bulgusu elde edilen çalışmalarda vardır. Bu çalışmaların büyük bir çoğunluğunda okula yönelik tutumda kadınların erkeklere göre daha pozitif bir algısı olduğu görülmüştür (Adıgüzel ve Karadaş, 2013; Alıcı, 2013; Gülcemal, 2019; Koç, 2019; Pişkin, 2005; Sözbilir, Akıllı ve Ozan, 2010).

Sınıf düzeyine göre öğrencilerin okula yönelik tutumları mevcut çalışmada farklılaştığı görülürken bu farklılığın dokuzuncu sınıf ile on birinci ve on ikinci sınıflar arasında olduğu bulunmuştur. Alanyazın incelendiğinde, mevcut çalışmada olduğu gibi lise öğrencileri ile gerçekleştirdikleri çalışmalarında anlamlı farklılıklar olduğu görülmüşsür. Alıcı (2013) çalışmasında 9. ve 10. sınıf öğrencilerinin 11. ve 12. sınıf öğrencilerine göre daha olumlu tutumlar sergilediklerini bulmuştur. Gülcemal (2019) ise 9. sınıfların 10., 11. ve 12. sınıflara göre okula yönelik daha olumlu bir algıya sahip oldukları 
bulgusuna ulaşmıştır. Sözbilir, Akıllı ve Ozan (2010) da çalışmalarında benzer bir şekilde sınıf seviyesi arttıkça okula yönelik tutum puanlarında azalma bulgusu elde etmişlerdir.

Niğde ili fen lisesi öğrencilerinin tercih ettikleri müzik türlerine göre okula yönelik tutumlarının farklılaşıp farklılaşmadığı incelenmiş ve tercih edilen müzik türleri arasında istatistiksel olarak anlamlı bir farklılık olduğu bulgusuna ulaşılmıştır. Alanyazına bakıldığında tercih edilen müzik türlerine göre okula yönelik tutumun farklılaşıp farklılaşmadığını inceleyen bir çalışmaya rastlanılmamıştır. Ancak yapılan alanyazın taramasında görülmektedir ki; Scheel ve Westefeld (1999) heavy metal müziğin gençler üzerinde kızgınlığa teşvik ettiğini, benzer şekilde Güner (1995'ten aktaran Sezer, 2011) gerçekleştirdiği çalışmasında heavy metal müzik türünü tercih eden gençlerin diğer müzik tarzlarını tercih edenlere göre daha saldırgan ve kaygılı olduğunu bulmuştur. Ögel, Ermağan, Eke ve Taner (2007) yaptıkları çalışmada birden fazla kere madde kullanımında bulunan ergenlerin rap-hip hop-techno-dans müziklerini tercih ettiklerini bulmuşlardır. Uluçay’ın (2018) çalışmasında dinlenilen müzik türünün şiddet eğilimini etkilediğini, Bozkurt (2015) ise öğrencilerin duygu durumlarına göre farklı müzik türleri dinlediklerini, Sezer (2011) gerçekleştirdiği çalışmada ise tercih edilen müziğin öfke ve psikolojik belirtiler üzerinde etkili olduğu sonucuna ulaşılmaktadır. Araştırma sonucunda elde edilen veriler ve alanyazında yer alan çalışmalar birlikte değerlendirildiğinde tercih edilen müzik türlerinin, öğrencilerin bireysel ruh durumlarına ve dolayısıyla hayatlarına etkisi olduğu yadsınamaz bir gerçekliktir. Mevcut çalışmada da bu durumun kanıtlarını ortaya koyan bulgular yer aldığı düşünülmektedir. Okula yönelik tutum açısından incelendiğinde, metal ve rock müzik türü ile ilgilenen öğrencilerin diğer türlere oranla daha olumsuz bir okul algısına sahip olduğu görülmektedir. Unutulmamalıdır ki eğitim hedefleri doğrultusunda öğrenci çıktıları elde edilebilmesi için okula yönelik tutum önemli bir kavramdır (Alıcı, 2013).

Öğrencilerin kimlik oluşturma yaşlarında farklı deneyimlerde bulunurken okula yönelik tutumlarında da farklılaşma olmaktadır. İnsanı her anlamda etkileyen müziğin firtınalı bir dönem olarak ifade edilebilecek olan ergenlik döneminde etkin ve doğru 
kullanılması gerekmektedir. Bu nedenle okullarda öğretmenlerin ders süreçlerinde kullandıkları, ders aralarında ve okulda gerçekleştirilen etkinliklerde kullanılacak müzik türlerinin seçiminin önemli olduğu düşünülmektedir. Özellikle öğrencilerin ruhsal durumlarında rahatlatıcı etkiye sahip müzik türlerinin dinletilmesinin eğitsel ve kişisel gelişimlerinde olumlu etkiler oluşturacağı ifade edilebilir. Öğrencilerin tercih ettikleri müzik türlerine yönelik yapılacak deneysel çalışmalar ile öğrencilerin okula yönelik tutumlarının farklılaşıp farklılaşmayacağı değerlendirmeleri gerçekleştirilebilir. Yapılan çalışma Niğde'de yer alan bir fen lisesinde gerçekleştirilmiş olup daha geniş evren ve örneklemdeki öğrencilerin katılımı ile gerçekleştirilecek çalışmalar daha verimli sonuçlar verebilecektir. 


\section{KAYNAKLAR}

Adıgüzel, A., ve Karadaş, H. (2013). Ortaöğretim öğrencilerinin okula ilişkin tutumlarının devamsızlık ve okul başarıları arasındaki ilişki. Yüzüncü Yıl Üniversitesi Eğitim Fakültesi Dergisi, 10(1), 49-66. https://dergipark.org.tr/en/download/article-file/146230 adresinden erişilmiştir.

Ainley, J. (1994). Multiple indicators of high school effectiveness. Paper presented at the Annual Meeting of the American Educational Research Association, New Orleans. https://files.eric.ed.gov/fulltext/ED372101.pdf adresinden erişilmiştir.

Alıcı, D. (2013). Okula yönelik tutum ölçeğinin geliştirilmesi: Güvenirlik ve geçerlik çalısması. Eğitim ve Bilim, 38(168), 318-331. http://eb.ted.org.tr/index.php/EB/article/view/1808/598 adresinden erişilmiştir.

Artemiz, B. (2009). Ergenlerin farkl müzik türlerine ilişskin ilgileri ile kişilik özellikleri arasındaki ilişskinin incelenmesi. Yayımlanmamı̧s yüksek lisans tezi, Maltepe Üniversitesi Sosyal Bilimler Enstitüsü, İstanbul.

Başaran, S.T. ve Yıldırım, K. (2017). Anne ve babaların okul anılarının çocuklarının okula karşı tutum ve akademik başarılarına etkisi. Ahi Evran Üniversitesi Kırşehir Eğitim Fakültesi Dergisi, 18(2), 331-351. https://toad.halileksi.net/sites/default/files/pdf/kuresel-okul-anilari-olcegitoad_0.pdf adresinden erişilmiştir.

Bozkurt, S., (2015). Ortaokul ögrencilerinin duygu durumlarina göre dinledikleri müzik türlerinin incelenmesi. Yayımlanmamı̧̧ Yüksek Lisans Tezi, Gaziosmanpaşa Üniversitesi Eğitim Bilimleri Enstitüsü, Tokat.

Büyüköztürk, Ş. (2017). Sosyal bilimler için veri analizi el kitabl: İstatistik, araştırma deseni, SPSS uygulamalarl ve yorum (23. baskl). Ankara: Pegem Yayınları.

Çoban, A. (2005). Müzikterapi. İstanbul: Timaş Yayınları.

Gülcemal, E. (2019). Okula yönelik tutum ve okul algısının öğrencilerin okulu kirma davranışı ile ilişkisi. Yayımlanmamış Doktora Tezi, Hacettepe Üniversitesi, Ankara.

Güven, E. (2017). Güzel sanatlar lisesi öğrencilerinin yalnızlık düzeyleri ile dinledikleri müzik türü arasındaki ilişki. Illkögrretim Online, 16(3), 1247-1261. doi: 10.17051/ilkonline.2017.330254.

Hair Jr, J. F., Hult, G. T. M., Ringle, C., \& Sarstedt, M. (2016). A primer on partial least squares structural equation modeling (PLS-SEM). Sage publications.

Karasar, N. (2017). Bilimsel araştırma yöntemi (32. Basım). İstanbul: Nobel Akademik Yayıncilik.

Koç, A. (2019). Ergenlerin sahip oldukları değerler ile okula yönelik tutumlart ve okul tükenmişlik düzeyleri arasındaki yordayıcı ilişkiler. Yayımlanmış Yüksek 
Lisans Tezi. Necmettin Erbakan Üniversitesi Eğitim Bilimleri Enstitüsü, Konya.

North, A. C., Desborough, L., \& Skarstein, L. (2005). Musical preference, deviance, and attitudes towards celebrities. Personality and Individual Differences, 38, 1903-1914. doi:10.1016/j.paid.2004.11.016.

Ögel, K., Ermağan E., Eke, C.Y. ve Taner, S. (2007). Madde deneyen ve denemeyen ergenlerde sosyal aktivitelere katılım: İstanbul Örneklemi, Journal Of Dependence, 8 (1), 18-23. http://www.ogelk.net/Dosyadepo/sosyalaktivite.pdf adresinden erişilmiştir.

Pişkin, B. (2005). Öğrencilerin okula yönelik tutumlarını etkileyen etmenler. Yayımlanmamış Yüksek Lisans Tezi. Kocaeli Üniversitesi, Sosyal Bilimler Enstitüsü, Sakarya.

Shah, Visal \& Shah, Anand, (June, 2018). Relationship between student perception of school worthiness and demographic factors. Frontiers in Education, 3(45),1 5. doi: $10.3389 /$ feduc. 2018.0004 .

Scheel, K. R. \& Westefeld, J.S. (1999). Heavy metal music and adolescent suicidality: An empirical investigation, adolescence. Summer, 34(134), 253-273. https://www.researchgate.net/profile/Karen_Scheel/publication/12805239_Hea vy_metal_music_and_adolescent_suicidality_An_empirical_investigation/links 1552d7ff50cf21acb092176ba.pdf adresinden erişilmiştir.

Sezer, F. (2011). Öfke ve psikolojik belirtiler üzerine müziğin etkisi. Uluslararası insan bilimleri dergisi, 8(1), 1472-1493. https://www.jhumansciences.com/ojs/index.php/IJHS/article/view/1732/732 adresinden erşilmiş̧ir.

Sözbilir, M., Akıllı, M. ve Ozan, C. (Haziran, 2010). Yusufeli'de Öğrencilerin Okula Karşı Tutumları. 10-12 Haziran 2010 Geçmişten Geleceğe Yusufeli Sетроzуити, Yusufeli Belediyesi, Yusufeli. 25/08/2019 tarihinde https://www.academia.edu/245272/Yusufelide_\%C3\%B6\%C4\%9Frencilerin_o kula_kar\% $\%$ 5\%9F\%C $4 \% \mathrm{~B} 1$ tutumlar\% $\%$ C4\%B1 adresinden indirilmiştir.

Uluçay, T. (2018). Lise öğrencilerinin dinledikleri müzik türlerinin şiddet eğilimlerine etkisi. Güzel Sanatlar Enstitüsü Dergisi, 41,135-153. doi: 10.32547/ataunigsed.450424

Williams, M. (2008). Violins over violence: mentoring at-risk youth with music education. W. Sharer (Ed.) In Pirate papers: a collection of student writing from English 1200 (3rd ed.) (92-69). East Carolina: Thomas Harriot Collage of Arts and Science Department of English Press.

Yağışan, N. (2013). Üniversite öğrencilerinin müzik tercihleri ve saldırganlıkla ilişkisi. Sanat Eğitimi Dergisi, 1 (2),t96-113. doi: 10.7816/sed-01-02-07. 


\section{ORCID}

Oğuz KOÇ(1) https://orcid.org/0000-0002-8656-6069

İdil EKİNAY ${ }^{(10}$ https://orcid.org/0000-0002-5973-9489 


\section{SUMMARY}

\section{Objective}

The aim of this study is to reveal whether science high school students' attitudes towards school differ according to their demographic characteristics and the types of music they prefer.

\section{Method}

The research was carried out in the Comparative Relational Scan Model. The study group consists of 334 students studying in a science high school in the province of Niğde in the 20182019 academic year. Information form and the attitude scale towards the school were used as the data collection tool. Firstly, the permission was obtained from the developer of the data collection tool from the Niğde Provincial Directorate of National Education in order to carry out the relevant research. Then, measurement tools were distributed to the students in the school by carrying out information activities about the purpose of the study. Afterwards, the forms were collected from the students and analysis processes were carried out. The data collected were transferred to the computer environment and research analyses were carried out with the SPSS 24.0 package program. In this process, it was tested whether the data met the criteria in order to analyze them within the frame of research questions.

\section{Results}

After the conditions were examined, independent sample t test was carried out. When the results were examined, it was determined that the attitude levels towards the school did not differ according to gender. One-way anova test was performed after examining the conditions. It is observed that the average attitude scores of students towards school make a significant difference according to their class levels. "Bonferroni" test, one of the Post Hoc tests, was used to determine which groups the differences were between. When the average of attitude levels towards the school according to the grade levels of the students was examined, it was found that ninth grade students' attitude levels towards the school were higher than the eleventh grade students and the twelfth grade students. While determining the method of analyzing whether students differ in their attitudes towards the school depending on their preferred music types, the number of students in the groups was examined. Kruskal Wallis H Test, which is a nonparametric test, was carried out due to the student groups under 30 in different music genre preferences. It was observed that there was a significant difference in the attitude score averages of the students according to their preferred music types.

\section{Discussion}

When the literature is analyzed, in line with the current study findings, studies with the findings that there is no difference in attitude towards school in terms of gender in high school students are observed. However, there are studies in which findings of difference are obtained. In the vast majority of these studies, it was observed that women have a more positive perception of attitude towards school than men. When the literature is analyzed, it is seen that there are significant differences in their studies with high school students as in the current study. Allcl (2013) found in 
his study that 9th and 10th grade students have more positive attitudes than 11th and 12th grade students. When we look at the literature, there is no study that examines whether the attitude towards school differs according to the preferred music types. However, it can be seen in the literature review that; Scheel and Westefeld (1999) found that heavy metal music encourages anger on young people, and Ögel, Ermağan, Eke and Taner (2007) found that adolescents who use substance more than once prefer rap-hip hop-techno-dance music. Music that affects people in every sense should be used effectively and correctly during adolescence, which can be expressed as a stormy period. With the experimental studies to be conducted for the music types that students prefer, evaluations can be made whether the students' attitudes towards school will differ or not. 
Ek-1. Niğde İl Milli Eğitim Müdürlüğü Onay Belgesi

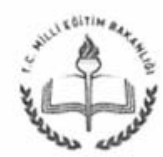

T.C.

NiĞDE VALiLiới

I1 Millî Eğitim Müdürlüğù

Sayı : 61900286-20-E. 24065158

13.12.2018

Konu : Anket Onay

Sayı ;

flgi : :11/12/2018 tarihli dilekçeniz.

Ilgi dilekçeniz ekinde bulunan anketiniz araştırma deg̃erlendirme komisyonumuz tarafindan incelenmis olup 'Fen Lisesi Öğrencilerinin Demografik Değiškenlere ve Tercił Ettikleri Müzik Türlerine Göre Okula Yönelik Tutumların Incelenmesi' başlıklı anketi

Lisesinde uygulanabilmesi için araştırma değerlendirme komisyonunun onayı ekte gőnderilmiștir.

Bilgilerinize rica ederim.

Sezai DEMIRHAN

Şube Müdürü

Ek: Onay (1 Sayfa)

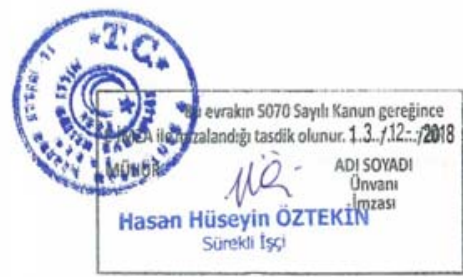

